\title{
Gini's transvariation analysis: an application on financial Crises in developing countries ${ }^{1}$
}

\begin{abstract}
The damage and the recurrence of financial crises have increased the concern of investors and policymakers on one hand and the interest of macroeconomists on the other. This paper presents an original non parametric methodology, whose aim is to give a very intuitive and rigorous method for variable selection in order to analyse financial crises. Transvariation analysis compares the distributions of two different groups of countries (sound and distressed) with respect to a single macroeconomic variable and selects the indicators on the basis of a low transvariation probability index. The current account deficit to GDP ratio, differently from other studies on financial crises, seems to be a suitable variable in discriminating distressed countries from sound ones, and the case of Argentina and Turkey confirms this finding.

JEL: G01, C14, F32

Keywords: Financial Crises; Current Account; Nonparametric Methods.
\end{abstract}

\section{Introduction}

During the last century, financial crises have been a recurrent and damaging phenomenon that not only has caused disruption to the affected economies, but also has worsened agents' expectations toward a future seen ever more uncertain. A series of panics and crises happened in the Pre-World War II period, from 1814 up to the Great Depression of 1929 (Calomiris-Gorton 1991), and many others occurred in the Post-World War II period as the collapse of the Exchange Rate Mechanism (ERM) of the European Monetary System in 1979 and in 1992, the Mexican crisis of 1995, the Asian Crisis of 1997, the Russian crisis of 1998, the Argentinean crisis of 2001. Nevertheless as Bordo and Eichengreen (2000) show, there were no major crises in the Bretton Woods era, whereas the post-1971 period has experienced numerous and disruptive financial crises. Bordo et al. (2001) find that financial crises after 1971 are different in terms of frequency and recurrence (only the period 1920-1930 may be compared with the recent post-1971 era), but in terms of output losses and length little has changed. The recent period is better than the inter war period, but still fairly bad. In particular, banking and twin crises (e.g. banking and currency crises) are more frequent than in every period (except the inter war period) and currency crises are much more frequent. In addition, they observe that emerging countries are more prone to crises. This thesis is corroborated by the recent findings of Reinhart and Rogoff (2009), who stress the weakness of the "this time is different" thesis. In particular, it is an illusion to believe that thanks to better macroeconomic policies and better screening by lenders "the world is not likely to again see a major wave of default". Recent experience shows the recurrence of serial defaults even though some countries thanks to better institutions are "graduating" from a history of serial defaults.

\footnotetext{
${ }^{1}$ We would like to thank Marco Riani for his useful advice.
} 
Starting from these stylized facts an obvious concern of empirical research, financial institutions and private investors has been the predictability of financial crises. Many academics and also some institutions as the IMF and Standard and Poor's, have introduced some indicators (or set of indicators) that could predict financial crises. The scope of the present analysis is to contribute to this literature on Early Warning Systems (EWS), by introducing a methodology (transvariation analysis) that is both rigorous and easy to apply. The result of the present research should induce to devote more attention to real factors in predicting financial crises, in particular to reassess the importance of the current account component of the balance of payments, in contrast with the recent almost exclusive attention to the financial account side. In particular, contrary to the current stream, which disregards the importance of current accounts deficits, focusing mainly on the financial account (and the related currency and maturity mismatch), our analysis suggests that unsound current accounts can strongly predict financial crises and the current account sharply discriminates between countries that are prone to crises and those who are not. The analysis does not underestimate the important recent contributions of Calvo (1998), who stressed the crucial role played by a weak financial sector, rather we want to stress that the current account more clearly than the financial account has been a key factor in distinguishing defaulting countries from sound countries.

The rest of the paper is organized as follows. Section 2 briefly introduces the role played by current account in the recent literature on financial crisis. Sections 3 and 4 focus on the evolution of EWS models in terms of methodologies, tasks and main results. Sections 5 and 6 introduce the methodology, the application and present the main results. Section 7 focuses on the importance of the variable current account in assessing the difference between Argentina and Turkey crisis episodes. Section 8 concludes.

\section{The role of current account deficits in predicting a crisis.}

Two big waves of current account deficit hit world economy in the last 30 years: the first, between the end of the '70s and early ' 80 s in Latin America, and the second in the '90s in East Asia. Both led to significant crises, the second being even bigger. The important point is that emerging market crises have large macroeconomic effects. In particular, when capitals flow inward a country can run large current account deficits, but when capitals flow out the current account has to be rebalanced very quickly, which is often economically and politically very costly. Indeed domestic spending must decline or taxes must increase relative to output to re-establish the balance. When domestic spending falls, a decrease in the output of non - tradables will follow, while a rise in the output of tradables is required to improve the current account. This will occur through a rise in the price of tradables relative to non - tradables, i.e. depreciation in the real exchange rate. These effects are painful when much of the domestic debt is denominated in foreign currency and/or is short term. In the 1980 emerging market economies (EMCs) had large current account deficits to GDP ratios. In 1982 in Latin America the deficit was 5 percent of GDP and then came the crises inducing the deficit to shrink to 0.3 percent of GDP in 1983. Finally in 1984 Latin America ran a surplus of 0.8 percent of GDP. However emerging market economies were close to balance between 1983 and 1991, but then came a period of generous market financing to East Asian countries in the '90s and in 
1996 the deficit in East Asia was 2.1 percent of GDP. When the 1997 crisis occurred East Asian was compelled to redress the balance running a surplus of $4.7 \%$ in $1998^{2}$.

In both episodes sudden cessation of capital flows ("sudden stops") forced the current account deficit to fall, the exchange rate to depreciate and the output to fall dramatically. Ever since emerging market economies seem to have learned the lessons and they were running current account surplus causing on the other hand what has been named the problem of "global imbalances", emerging economies. In other words, EMC's have realized that the counterpart of capital inflows was running huge current account deficits, which implied financial crises. In particular the interaction between irresponsible lending - moral hazard fostered by international institutions -, and unregulated borrowing - borrowing short term and in foreign currency - has proved fatal to emerging market countries. In the last decade the result has been on one hand to improve the current account sustainability and on the other hand the fear of running current account deficits. The latter implies that the EMCs governments have converted capital inflows in foreign currency reserves.

The role played by current account deficits in triggering a crisis has been central to many models since the late '70s. The first generation model of financial crises introduced by Krugman (1979) who developed for pegged exchange rate regimes a model introduced by Salant and Henderson (1978) pointed out the relevance of having consistent fiscal policies and exchange rate regimes ${ }^{4}$.

Second generation models have been introduced by Obstfeld and Rogoff (1995) to deal with EMS crises in the 1990s. The main tenet of these models is that crises are selffulfilling phenomena in a context of multiple Nash equilibria. According to these models, while good fundamentals avoid crises and really bad ones lead to crises, there are certain intermediate values of fundamentals in which both, the good and the bad scenario, are possible outcomes The implications of these models were that having sound current account does not always guarantee that countries will escape a crisis.

In the last decade many authors have analysed whether crises were preceded by current account deficits or not. Some authors like Radelet and Sachs (1998a, 1998b), have stressed the role of financial panic as an essential element in exacerbating the crises. The key elements of the Asian financial crises (AFC) were that the crises were largely unanticipated, they involved considerable lending to debtors that were not protected by state guarantees, economic fundamentals while not completely sound, were substantially good. The only critical points such as growing current account deficits, overvalued exchange rates and slowing export growth were not so serious as to predict an impeding major crisis. Only the financial sector with its large imbalances in the maturity and denomination of the currency, raised the most serious doubts about the stability of the

\footnotetext{
${ }^{2}$ See Williamson (2005) for a detailed account of how current account deficit led to crises in emerging market countries.

${ }^{3}$ For an account on global imbalances, its causes and effects see Eichengreen (2007), Edwards (2007), Wolf (2009),

${ }^{4}$ Krugman's model has been perfected by Flood and Garber (1984), who determined the timing of a crisis.
} 
system. Thus the crisis is due to co-ordination failure and not to bad fundamentals in the current account.

A different perspective has been put forward by Corsetti, Pesenti and Roubini (1999) who has stressed the role of moral hazard caused by money-back guarantees for depositors and limited liability for lenders that led to excessive investment (overinvestment problem). Thus the problem was not one of panic and failure of co-ordination among creditors, but one of over-investment. These authors opened the way to third generation model of crisis, stressing again the role of sound fundamentals.

Both interpretations deserve attention, because they focus on key elements of the East Asian financial crisis. Radelet and Sachs' interpretation helps us understanding that some indicators, usually adopted to screen the presence of distress, are no longer the unique ones (in particular, budget deficits as to the fiscal policy and interest rates as to the monetary policy), while Corsetti et al. (1999)'s focuses on the important role played by moral hazard in the financial and corporate system.

Some authors, as Chang and Velasco (1998), have formalized the maturity mismatch problem, and Aghion, Bacchetta and Banerjee (2000, 2001) have focused their attention on the currency mismatch phenomenon. This last approach has restored the relevance of balance sheet, though still including the possibility of multiple Nash equilibria ${ }^{5}$.

Some studies building on Calvo have stressed the role of capital account rather than current account imbalances. Indeed Calvo (2000) has focused its attention on the vulnerability of the balance of payments caused by capital reversals ${ }^{6}$. He has shown how a currency crisis is possible even in the absence of a prior current account deficit. Edwards (2002) conducted a massive investigation on the importance current account and questioned its relevance, concluding that it is not possible to support the thesis that countries with high current account deficits (arbitrarily defined) must face a crisis. However he added that more broadly defined current account deficits - in terms of the costs involved in running very large deficits - almost inevitably leads to a crisis. Moreover if Africa is excluded - and Edwards provides reasons to do that - even current account strictly defined raises the probability of crisis. Finally, he concludes contrary to recent claims suggesting the irrelevance of current account deficits, "large deficits should be a cause for concern"7. These conclusions have been strengthened by further research of the same author (Edwards (2004)).

\footnotetext{
5 This has led some authors, as Alonso Neira (2005), to question whether we should speak of third generation or whether these models are just an extension of the two previous ones. But while in the first generation models a crucial role was played by the fundamentals of the economy (current accounts, fiscal deficits) in third generation models attention is devoted to banks', firms' and the financial sector's balance sheet, in order to single out the variable(s) that could help predict the crisis. Third generation models were developed out of the consideration that crises in the late 1990 s occurred in countries with sound fundamentals, so the weakness was looked for in the banking and financial sector.

${ }^{6}$ The idea that currency crises are due in our days to capital accounts problems rather than current account deficit had been presented at the Munich Lectures by Dornbusch in 1998 (see Dornbusch and Fischer (2003).)

${ }^{7}$ Edwards (2005) has analysed current account deficits over the period 1970 - 2002, studying the implications in terms of GDP loss for the U.S. of redressing the current account deficit.
} 
To summarise, the fear of running current account deficits may be due to the fear of generating a currency mismatch on the balance sheet; large current account seems to trigger capital outflows, when signals of vulnerability appear either at the domestic or the international level; re-establishing the balance in the current account requires a depreciation in the real exchange rate, which is painful in the presence of currency mismatches; the latter is worsened when debt is short term and can easily fly out. Finally the "fear of floating", generated by the desire to avoid currency mismatches has led to undervaluaed exchange and current account surpluses, which is what we currently observe in most EMCs and on the other has concurred to generate US current account deficits (the US government knows it will never suffer from the double mismatch occurred to EMCs). In what follows we want to show that the fear by EMCs is well grounded on the basis of the fact that the current account deficit is the best predictor of an impending crisis.

\section{Non parametric EWS models}

Theories on crises are very important in determining the list of economic indicators, but EWS models have the power of testing whether these indicators are good predictors of financial crises without estimating any particular speculative attack theory. The Early Warning Systems models can be divided into three groups in terms of methodologies:

- non parametric (signal approach);

- parametric (probit-logit, multinomial logit, markov chains);

- non-parametric and parametric (event studies and statistical distribution comparisons, supplemented by multivariate regression).

Kaminsky and Reinhart (1999) and Kaminsky (1999) introduce a pure non parametric approach to evaluate the usefulness of several variables in signaling an impending crisis. The aim of this approach is to monitor the evolution of a number of economic indicators, which are said to send a warning signal if their value exceeds a certain 'threshold', calculated so as to strike a balance between the risks of having many false signals and the risk of missing many crises. The signal approach, not only ranks the indicators according to their ability to signal a crisis, but also tabulates the average number of months in advance of the crisis when the first signal occurs and the level of persistence of the indicator. The main drawbacks of this approach are that a variable can send a signal at whatever distance from the critical 'threshold' and that the approach is univariate. In order to address these issues, Manasse, Roubini, Schimmelpfennig (2003) and Kaminsky (2006) introduce a multivariate signaling approach, which overcomes the unknown nonlinearity that characterizes the crisis phenomena. The latter methodology (Regression Tree Analysis) allows the data to determine the number and characteristics of classes of crisis. As in the univariate signal approach, the algorithm chooses a 'threshold' for each indicator to minimize its noise-to-signal ratio, and selects the indicator with the lowest ratio. All the observations are then separated into two groups for each of which the methodology is repeated. Reinhart and Reinhart (2010) use a different non parametric methodology to address the question whether the decade after a crisis is systematically different from the decade before. They examine if some key macroeconomic indicators seem to come from the same distribution before and after a dislocating event through the use of standard statistical tests, such as the Kolmogorov-Smirnoff (K-S). They apply their 
methodology to 15 crises post World War II and 3 synchronized global contractions (1929 stock market crash, 1973 oil shock and the 2007 US subprime collapse).

The second set of studies are pure parametric approaches that involve usually Logit, Probit, Multinomial Logit or Markov Switching Models. ${ }^{8}$

Regarding the third set of empirical studies, they combine both non parametric (event studies, or quantile analysis) and parametric techniques (country regressions). The event studies were used for example by Eichengreen, Rose and Wyplosz (1995), Frankel and Rose (1996), Edwards and Santaella (1993), and more recently by Aziz, Caramazza and Salgado (2000). Edwards and Santaella (1993) combines non parametric tests with cross country regression to understand 48 devaluations in the developing countries that took place during the Bretton Woods period (1945-71). The control group consists of the 24 developing countries that maintained a fixed nominal exchange rate for at least ten years. They summarize the behavior of some macroeconomic indicators in the two groups of countries by comparing the statistical distribution of the two groups, using quartiles. Eichengreen, Rose and Wyplosz (1995), Frankel and Rose (1996) combine event study analysis with the use of the graphical techniques and multivariate regression. In both studies the control group is given by the 'tranquil' period for the same group of countries. In the graphical approach, a graph for each variable is constructed in order to study a particular 'event' that can be a currency crash, but also a depreciation event. For each indicator, the average value of the 'tranquil' period is thus compared to the average values around the event and the differences between the two groups of observations are tested for statistical significance. The advantages of the event studies methodologies, as underlined by Aziz, Caramazza and Salgado (2000) can be found in the simplicity of the approach, it does not impose parametric structure on the data, it is more informative in extracting patterns of crises. In more general terms, all non parametric methodologies overcome the main pitfall of parametric empirical models that assume particular distributions of the economic variables which - on the contrary - could be affected by deep changes across time such as to make unsuitable the tests used.

\section{What variables do EWS models consider as important predictors?}

Eichengreen, Rose and Wyplosz (1995) find that devaluation are preceded by political instability, budget and current account deficits and fast growth of money and prices, in contrast they find that few consistent correlations link regime transition like floatation or fixing to macroeconomic or political variables and they conclude that there are no clear early warning signals of many speculative attacks. Edwards and Santaella (1993) emphasize on the importance of domestic credit and fiscal policy expansion indicators, but also the worsening of the current account deficit and the capital flight in understanding the 69 devaluation episodes object of their study. Frankel Rose (1996) show, in line with most studies, both with graphical and regression analysis, that crashes tend to occur when FDI inflows dry up, when reserves are low, when domestic credit growth is high, when world interest rates rise and when real exchange rate show overvaluation. On the other hand they put in evidence that current account deficits and government budget deficits do not play a role in explaining crashes.

\footnotetext{
${ }^{8}$ See Bussiere Fratzscher (2006) for multinomial logit, Abiad (2003), Martinez Peria (2002), Cerra Saxena (2000) for Markov Switching Models.
} 
Kaminsky (1999), using the signaling approach, provides some information on the performance of individual indicators in forecasting currency and banking crises. If we consider only currency crises then, according to Kaminsky (1999), high world interest rates, together with increasing gross foreign debt (the ratio of domestic residents' liabilities in banks overseas to foreign exchange reserves), positive capital flight (the ratio of domestic residents' assets in banks overseas to foreign exchange reserves) and the ratio of short term maturity foreign debt to total foreign debt (which captures liquidity problems) are good indicators. If we consider banking crises, then the best indicators are the ones linked to the liberalization of the capital account and the domestic financial sector (M2 multiplier, domestic credit/GDP and stock prices). The indicators that can be excluded from Kaminsky's (1999) univariate analysis are: lending/deposit rate ratio, imports and bank deposits. We would like to notice that the current account deficit/GDP is not part of the list of variables considered by Kaminsky (1999), but other indicators such as exports, imports, the terms of trade and the real exchange rate are analyzed as those variables that are linked with current account problems. $^{9}$

A more recent battery of EWS models tend to focus more on the ability of the models of predicting the timing of the crises (Bussiere Fratzscher, 2006) or on the ability of the models to explain the different varieties of crises (Kaminsky 2006 and Arias and Erlandsson 2003) rather than focusing on the macroeconomic indicators. A recent paper by Frankel and Saravelos (2010) examines the success of the indicators identified in the earlier literature in predicting the recent 2008-09 financial crisis incidence and lends support to the usefulness of the leading indicators. The authors address the main problems concerning the EWS literature, namely different definitions of crisis, different types of crisis and, most importantly, selection bias due to an ex-post identification of variables. Most relevant to the scope of this paper is the latter, which we address by using a methodology aimed at selecting the variable that proves most effective in predicting the crisis $^{10}$. According to Frankel and Saravelos (2010) the current account to GDP, international reserves, real exchange rate overvaluation, credit growth, external and short term debt stood out as useful leading indicators of the recent global crisis. In particular, in their review of the literature, while figuring as fourth in the ranking of predictors the current account has often but not always exhibited statistical significance, whereas reserves rank first. Their study confirm the significance of both reserves and current account. Our investigation shows that $\mathrm{CAD}$ has much stronger predictive power than reserves to GDP ratio ${ }^{11}$.

\section{Transvariation analysis: where do we stand?}

As in the event studies, we consider those variables that are suggested by the theory literature on financial crises, in the period that leads up to the event we are interested in. We use annual data and we compare the behavior of two groups of countries: the group of developing countries that experienced a crisis and the group of sound developed

\footnotetext{
${ }^{9}$ See Kaminsky (1999) for the full list of indicators considered.

${ }^{10}$ Berg et al. (2004) have analysed some out-of-sample assessments of the ability of early warning system to predict the incidence of crises before their occurrence.

11 This finding is consistent with Blanchard et al. (2009) and Rose and Spiegel (2009) who downplay the role of reserves.
} 
countries. Our aim is not to predict the timing of a crisis, but we find much more useful, for policy implications, to study the behavior of macroeconomic indicators that can be controlled by policymakers and to study them enough time in advance in order to be able to implement the right changes. The approach is non parametric, gaining all the advantages of non parametric techniques, and very simple to understand and implement thus in a rigorous way. We consider different episodes of crisis that have different characteristics so we are interested in searching the common elements. Our approach does not depend on arbitrarily chosen 'thresholds' as the signaling approach, but we base our analysis on the calculation of a transvariation probability index that measures the overlapping area between the distributions of the two group of countries considered with respect to each economic indicator. The approach is univariate, but a multivariate version of transvariation analysis, that takes into account the correlation between variables, can be implemented.

The basic idea of transvariation analysis we would like to explain in this paper is quite simple. Let us suppose to face a whole of units (men, families, firms), characterized by several variables (rate of blood pressure, cholesterol level, but also, financial ratios, patrimonial indicators) divide them into two groups, respectively healthy and unhealthy men, distressed and sound firms, safe and insolvent families. Once we report the two density distributions of each variable, each for the two groups, on the same graph, we observe different overlapping areas: the transvariation area. If now we imagine ignoring which of the two groups the different units share, but at the same time we have the task of classifying correctly the units in the two groups by means of only one variable, we can properly do this by choosing the variable whose overlapping area - transvariation - is quite small. Transvariation analysis has been developed by Gini (1916, 1951) in connection with zoological and anthropometric studies. Deutsch and Silber (1997) have used transvariation analysis to study income distribution in Israel. Skirmantas (2005) has used the same approach to verify the physical difference between autistic and healthy children with reference to the two distributions of serotonin. Another approach similar to the analysis of transvariation is the 'affinity analysis' developed by Bhattacharyya (1943), Matusita (1956), Kratzanowski (1995). In the following subsections we will describe the methodology used in detail.

\subsection{The methodology: transvariation analysis}

Let $\mathrm{x}_{\mathrm{i}}$ be any quantitative variable (height, weight, income, inflation, etc.) and $\mathrm{K}$ and $\mathrm{H}$ two groups of units (men, women, firms, countries, etc.), composed with respect to the same variable, of numerousness $n$ and $m$.

We then define:

- $\mathrm{x}_{1, \mathrm{k}}, \mathrm{x}_{2, \mathrm{k}}, \ldots, \mathrm{x}_{\mathrm{n}, \mathrm{k}}$ as the ordered measures of the units composing group $\mathrm{K}$;

- $\mathrm{x}_{1, \mathrm{~h}}, \mathrm{x}_{2, \mathrm{~h}}, \ldots, \mathrm{x}_{\mathrm{m}, \mathrm{h}}$ as the ordered measures of the units composing group $\mathrm{H}$.

Chosen the median as the mean value of the distributions, let us assume that the following inequality holds:

$\mathrm{M}_{\mathrm{k}}>\mathrm{M}_{\mathrm{h}}$ 
Given (1), if we compare each unit of group $\mathrm{K}$ with each unit of group $\mathrm{H}$, getting a total of $n \cdot m$ comparisons, we have that some comparisons obey the following inequality

$\mathrm{X}_{\mathrm{i}, \mathrm{k}}>\mathrm{x}_{\mathrm{j}, \mathrm{h},}$

others respect this relation

$\mathrm{X}_{\mathrm{i}, \mathrm{k}}=\mathrm{x}_{\mathrm{j}, \mathrm{h}}$

and finally others follow this inequality

$\mathrm{x}_{\mathrm{i}, \mathrm{k}}<\mathrm{x}_{\mathrm{j}, \mathrm{h}}$,

where $\mathrm{i}=1,2, \ldots, \mathrm{n}$ and $\mathrm{j}=1,2, \ldots, \mathrm{m}$. We have transvariation when a part of the comparisons obeys to inequality (4). From a graphical point of view it is possible to draw the transvariation area for relations (2) and (4).

If $\mathrm{x}_{\mathrm{i}, \mathrm{k}}>\mathrm{x}_{\mathrm{j}, \mathrm{h}}$, for each of the $n \cdot m$ comparisons, the density distribution of group $\mathrm{K}$ is completely separated from the density distribution of group $\mathrm{H}$.

Alternatively, if for some cases $\mathrm{x}_{\mathrm{i}, \mathrm{k}}<\mathrm{x}_{\mathrm{j}, \mathrm{h}}$, the two density distributions are characterized by an overlapping area, the area of transvariation.

If for a high number of cases $\mathrm{x}_{\mathrm{i}, \mathrm{k}}<\mathrm{x}_{\mathrm{j}, \mathrm{h}}$, then the two density distributions are characterized by a large overlapping area, which corresponds to a lower variable's discriminating power.

The distributions are very well shaped, but this is not a necessary prerequisite of transvariation analysis, being this statistical tool essentially non parametric and, therefore, independent from whatever hypothesis on the distributions of the groups.

The transvariation probability index is defined with respect to the median as the following ratio:

$2 \cdot\left(\mathrm{T}_{\mathrm{h}, \mathrm{k}} / \mathrm{n} \cdot \mathrm{m}\right)$

where:

- $\mathrm{T}_{\mathrm{h}, \mathrm{k}}$ is the number of cases of transvariation, increased by half of the number of cases in which $\mathrm{x}_{\mathrm{i}, \mathrm{k}}=\mathrm{x}_{\mathrm{j}, \mathrm{h}}$;

- $\mathrm{n} \cdot \mathrm{m}$ is the number of possible comparisons.

The index is defined in the interval $[0,1]$.

Increasing values of the index involve larger and larger overlapping areas.

In the case of equal medians, which imply a perfect overlapping of the two distributions, the index assumes value 1 .

At the opposite, decreasing values of the index are associated with lower and lower overlapping areas. For value of the index equal to zero the two distributions are perfectly separated.

The probability of transvariation derives from 3 different causes:

- the distance between the medians of the two groups; 
- the degree of variability of the variable;

- the shape of the density distributions.

Given the same variability and the same shape of the two distributions, a lower distance between the medians can produce transvariation. If, on the contrary, we have the same distance between the medians and the same shape of the two density distributions, it is the different variability that can cause transvariation. Finally, given the same distance between the medians and the same variability, transvariation can be primed by a change in the shape. The different causes of transvariation are depicted in figure 1.

\section{A dynamic integration: speed of run}

Transvariation analysis is a relevant expedient to individualize a correct variable in order to classify correctly two groups of statistical units - countries - according to a precise profile, which is to be or not proximate to default in our case.

Once individualized the correct variable it is necessary to explain how to use it correctly in a dynamic and not only static framework.

It can in fact happen that the available information is not only supplied for one 'point', but also for a span of time as it happens in macroeconomics where the national accounts of a country are available for a series of years.

Our suggestion is to use the speed of run. This is the number of times - years in national accounts - the chosen predictive variable maintains the same sign. The change of the sign involves a new begin of the counting. Rationale of this procedure is that the persistence of the sign is a proof of an increasing intensity of the variable and vice versa.

\section{The application}

Imagine to position on a space $\langle\mathrm{d}, \mathrm{x}\rangle-$ where $\mathrm{d}$ is the probability density function and $\mathrm{x}$ the economic variable - two groups of countries, the sound and the distressed before their financial crisis. Gini's transvariation index measures, for the same variable, the overlapping of the two groups' distributions. The methodology selects those variables that better separate the two groups of countries not only in a static, but also in a dynamic framework. This methodology allows to select as most informative for financial distress analysis only those variables associated with a decreasing overlapping of the two distributions as the year of the crisis approaches.

In the following application we would like to focus on two different samples. The first reflects the most serious crisis episodes of the nineties that are linked with sovereign debt default and/or debt servicing difficulty, while the second is taken from Frankel and Rose (1996) dataset which comprises around 71 countries.

\subsection{The first sample: debt crises of the nineties}

In this first sample we construct the group of distressed countries considering those countries/events, during the nineties, that experienced a default on their external debt or in more general terms a debt servicing difficulty. Argentina (2001), Ecuador (1999), Ivory Coast (2000), Pakistan (1999), Peru (2000), Russia (1998), Ukraine (2000), Venezuela (1998), Indonesia (1997) are chosen by taking Moody's definition of sovereign bond default. ${ }^{12}$ To this list we add Mexico (1994), Brazil (1999) and the

\footnotetext{
12 Moody's Global Credit Research, Sovereign Default and recovery Rates, 1983-2007, March 2008.
} 
remaining so called Asian Tigers, because, even though they did not experience a default, they avoided a debt servicing crisis via large amounts of official support by the international financial institutions (IFIs) ${ }^{13}$. Mexico, Brazil, Korea and Thailand were also considered by Manasse, Roubini and Schimmelpfennig (2003) as countries experiencing debt difficulties.

We use two different control groups in order to calculate the transvariation probability index:

- the first comprises the group of developed countries in a tranquil year (1999) ${ }^{14}$, so that we are confident that the group is composed by sound countries and to avoid imprecise and ad hoc definitions of 'tranquil' periods that might bias the results;

- the second control group collects the same developing countries that experienced a debt crisis, but considered in a 'tranquil' period, selected to be four years after the crisis. The rationale of this choice is to make available a control group characterized by the same economic structure of the "distressed" countries, but not hit by a crisis. We select four years after the crisis as a 'tranquil' year, because we assume that these countries would be again sound after the rehabilitation programs put in place by the governments in consequence of the crisis.

Both the theoretical and the empirical literature suggest different crisis' symptoms: expansionary monetary and fiscal policies, recessions, real exchange rate appreciations, high inflation, exaggerated credit-cycles, loss of competitiveness and deterioration of the current account, high domestic and foreign interest rates etc.

According to these different symptoms we can divide the macroeconomic indicators as follows:

- over borrowing (domestic credit/GDP);

- growth slowdown (GDP growth, real deposit rate);

- capital account indicators (reserve variation, M2/reserves);

- current account indicators (current account deficit/GDP, trade balance/GDP, investment/GDP);

- monetary indicators (M2/GDP, M2/reserves, nominal deposit rate, real deposit rate, inflation). ${ }^{15}$

We consider the variation of all these variables (except GDP growth, CAD/GDP, TB/GDP), in accordance with Kaminsky (1999).

\subsection{The second sample: Frankel and Rose dataset}

With the aim of improving the robustness of our exercise, we extend our analysis to a different time period (1971 - 1992) and a different definition of crisis (currency crises).

We construct the second sample from Frankel and Rose (1996) annual data on developed countries from 1971 to 1992 and we define currency crises as a depreciation of the nominal exchange rate of 25 p.c. that is also at least a 10 p.c. increase in the rate of

\footnotetext{
${ }^{13}$ Malaysia, was the only country that avoided debt default and restructuring, but we decided to keep it in the sample because it was heavily involved in the crisis of 1997-1998 and it experienced a decline in Real GDP as high as 7.4 percent.

${ }_{14}$ The developed countries considered are: Austria, Belgium, Luxembourg, the Netherlands, Ireland, Spain, Italy, Germany, France, Norway, Sweden, Denmark, Switzerland, the UK, Iceland, Finland, Australia, Japan, Canada, New Zealand.

15 The source of these indicators is IMF International Financial Statistics Yearbook, 2001.
} 
change of nominal depreciation. The sample is constructed similarly to Frankel and Rose (1996) by considering for each country all the observations starting from the year of the crisis up to three years before.

Also for this second dataset, we use two control groups represented by developed countries ${ }^{16}$ in two different intervals of time: a more recent one $(2004-2006)$, in order to maximize data availability ${ }^{17}$ and a second one chosen within the sample of reference (1971 - 1973). After 1974 it would have been risky to consider the developed countries as controls, because the countries are subject to two major shocks given by huge increases in oil prices (1974 and 1979) and in some cases wages, which would make them less reliable as a control group.

The variables considered are also very similar to Frankel and Rose (1996), we can divide them as follows:

- debt variables (the ratio of external debt to GDP, short term debt to external debt, government debt to external debt);

- current account indicators (current account deficit/GDP, investment/GDP);

- capital account indicators (reserve variation);

- monetary indicators (M2 growth and inflation);

- a measure of the over borrowing (domestic credit to GDP);

- a measure of recession (GDP growth). ${ }^{18}$

All the variables except CAD (current account deficit) and investment/GDP are in variation terms.

\footnotetext{
${ }^{16}$ Same countries as in the previous analysis.

17 The analysis, which involves the control group in the years 2004-2006, is more complete in terms of data availability, debt variables are in fact not available in earlier years.

${ }^{18}$ The source of these indicators is World Bank, World Bank Development Indicators.
} 


\section{Results for the first sample}

In this paragraph we present the main results referred to the first sample of crises, focusing on the quartile analysis - which captures a preliminary comparison between the two distributions - on the transvariation probability indexes and finally on the speed of run. As specified in the previous paragraph, even though the quartile analysis should be very close to the transvariation probability index results, the index is more rigorous because it includes all those cases in which the causes of transvariation are not linked to a lower distance of the medians and quartiles, but to a different variability or a different shape of the two distributions.

\subsection{Quartile analysis}

Table 1 reports the quartile analysis for each variable. From the table we can see that it is possible to compare the distributions of the distressed countries up to 4 years before the crisis, and also the same distributions with the two control groups. We find this table very informative, because it pictures the difference in terms of values, between sound and distressed countries and permits to understand the evolution in time of each variable approaching the crisis. The reserves' variation becomes negative, the ratio M2/reserves increases, domestic credit/GDP - which is an indicator of the fragility of the banking system and also an indicator of the amount of money supply - together with M2/GDP and the real deposit rate, increases. GDP growth, which is an indicator of recession, and inflation decrease. The current account deficit (CAD)/GDP becomes more and more negative approaching the crisis year and the distribution of the distressed countries moves away from the distribution of the sound countries. Investment to GDP ratio and saving to GDP ratio, which can be interpreted as the causes of the deficit, behave in a heterogeneous way. With one of the two control samples the trade balance/GDP is characterized by an almost complete overlapping of the distributions.

\subsection{Transvariation probability index}

Table 2 and 3 report the transvariation probability index in the two different control groups which are developed countries in 1999 and developing countries taken 4 years after the crisis respectively.

The CAD to GDP ratio, in both tables, is highlighted as the best indicator in terms of crisis prediction for two main reasons.

Firstly, the variable is characterized by a very low index that decreases as the crisis year approaches. Secondly, the variable assumes very strong leading features given by the fact that the indicator distinguishes between sound and distressed at least up to 4 years before the crisis.

The remaining indicators are characterized either by a very high index or a completely unstable development which alternates bigger and smaller overlapping areas.

M2/reserves in both exercises and the Trade Balance to GDP only in the latter case, are the second best indicators. The variation of reserves, in the second analysis, correctly distinguishes between the two groups of countries only in the year of the crisis, loosing completely its leading feature.

\subsection{The speed of run}


Once individualized the correct variable (CAD/GDP) it is necessary to explain how to use it correctly in a dynamic and not only static framework. Rationale of this procedure is that the persistence of the sign is a proof of an increasing intensity of the variable and vice versa. Most of the distressed countries experienced current account deficits for a long span of years continuously. Their speed of run is consequently very high. The most prominent cases are those of Indonesia, Malaysia, Philippines, Thailand, Peru and above all Argentina. The speed of run has been more modest for Korea and Ecuador, for Ukraine we don't have all the data and in Mexico's case we only consider four years before the crisis. The great exception is Russia and Venezuela with speed zero (even if its surpluses decrease monotonically). In table 4 the current account sign and the speed of run score are reported. The speed of run helps also to understand why Turkey - a very relevant country according to the size of its economy, population and exposure toward the international financial system - has been wrongly classified as risky as other SouthEast Asian countries and Argentina. Factors at the base of this misleading classification are: hyperinflation, very high public deficit, recurrent deficit of current accounts in time. This wide spread misunderstanding of Turkey's probability of default is immediately corrected if the speed of run is considered. From table 4 we notice the difference in the score between Turkey (2) and Argentina (10).

\section{Results: Frankel and Rose (1996) dataset}

This section reports the results related to the rich sample taken from Frankel and Rose (1996) that considers a broader definition of country crisis. The results are summarized only by the transvariation probability index without considering the dynamics. For both control groups table 5 shows that the variable CAD/GDP has the most informative power compared to the other variables.

\section{Conclusions and further research}

In this paper we have made use of a statistical methodology called 'transvariation analysis', developed by the Italian statistician C. Gini, to study and assess the predictive power of macroeconomic variables in the forecast of financial crises in developing countries.

Two groups of countries, sound and distressed, have been formed. For each country composing the two groups we selected a range of macroeconomic indicators, broadly used in the literature, and then, with these indicators, we constructed a correspondent couple of distributions with respect to the two groups of countries.

Because the core of transvariation analysis is the measurement of the overlapping of the two distributions our procedure is made of three steps.

The first is quartile analysis. The second step is the calculation of the transvariation probability index. The predictive power of the index has to involve low and decreasing values of it.

Because distress country analysis is developed on the basis of several years, it is necessary to join the use of the current account deficit variable with the counting of its speed of run. The calculated scores of the speed supply a good measure of the intensity of current account deficit in time.

The same procedure has been applied to the crises of the nineties revealing a strong predictive power of the CAD to GDP. 
In order to test the robustness of this result on a different sample, we decided to calculate the transvariation probability index on Frankel and Rose (1996) sample of 71 countries that experienced a currency crash (measured in terms of a substantial depreciation of the nominal exchange rate). Even considering this broader definition of crisis we have shown that $\mathrm{CAD} / \mathrm{GDP}$ is still the macroeconomic indicator with the highest predictive power according to this statistical methodology.

Because Gini also extended the analysis of transvariation to the case of two and more variables, it might be fruitful in the future to apply the multivariate version of this statistical tool to select a composite leading indicator for financial crises able to synthesizes the single variables. The first step of this second procedure of transvariation analysis would be to project the units of the two groups of countries (distressed and sound), which are now n-dimensional units, on a line, the second step is to apply univariate transvariation analysis to the two groups of countries with respect to the artificial variable created. Since our paper ends with 2001, it might potentially be extended to recent crisis episodes, in which the problem of global imbalances is a key figure (see among others Eichengreen (2007), Corden (2007), Cooper (2007), Caballero (2010) and Reinhart and Reinhart (2010)). In a future investigation we aim to apply this methodology to the 2007-2008 financial crisis, including a multivariate analysis, in order to check the robustness of the method and the usefulness of the CAD as powerful predictor. 


\section{References}

AAVV (1960) Transvariazione, Memorie DiMetodologie Statistiche, Libreria Goliardica, Roma.

Abiad A. (2003) Early-warning systems: A survey and a regime-switching approach, IMF working paper, 03/32.

Aghion P., Bacchetta P. and Banerjee A. (2000) A simple model of monetary policy and currency crises, European Economic Review, 44, 728-738.

Aghion P., Bacchetta P. and Banerjee A. (2001) Currency crises and monetary policy in an economy with credit constraints, European Economic Review, 45, 1121-1150.

Alonso Neira M.A. (2005) Las teorías monetarias del ciclo en el marco de la literatura sobre ciclos econ'omicos, Libertas, 43.

Arias G. and Erlandsson U. (2003) Regime switching as an alternative early warning system of currency crises: An application to south-east Asia, IMF Working papers, 03/32.

Aziz J., Caramazza F. and Salgado R. (2000) Currency crises: In search of common elements, IMF Working paper, 00/67.

Berg A., Borensztein E. and Pattillo C. (2004) Assessing early warning systems: how have they worked in practice?, IMF Working paper, 04/52.

Bhattacharyya A. (1943) On a measure of divergence between two statistical populations defined by their probability distributions, Bulletin of the Calcutta Mathematical Society, $55-78$.

Blanchard O., H. Faruqee and V. Klyuev (2009) Did Foreign Reserves Help Weather the Crisis? IMF Survey Magazine, October.

Bordo M. and Eichengreen B. (1999) Is our Current International Economic Environment Unusually Crisis Prone?, Reserve Bank of Australia, Sydney, 18-74.

Bordo M., Eichengreen B., Klingebiel D. and Martinez-Peria M. (2001) Is the crisis problem growing more severe?, Economic Policy, 16 (32), 51-82.

Bussiere M. and Fratzscher M. (2006) Towards a new early warning system of financial crises, Journal of International Money and Finance, 25, 953-973.

Caballero R. (2010) The "Other" Imbalance and the Financial Crisis, NBER WPO 15636.

Calomiris C.W. and Gorton G. (1991) The origins of banking panics: Models, fact and bank regulation, in: Financial Markets and Financial Crises, Hubbard R.G., ed. 
Calvo G. (1998) Capital flows and capital-market crises: The simple economics of sudden stops, Journal of Applied Economics, 1, 35-54.

Calvo, G. (2000), Balance of Payments Crises in Emerging Markets: Large Capital Inflows and Sovereign Governments, in P. Krugman (ed.) Currency Crises, University of Chicago Press, Chicago.

Cerra, V. and \& Saxena, S. C., (2002), Contagion, Monsoons, and Domestic Turmoil in Indonesia's Currency Crisis, Review of International Economics, vol. 10(1), pages 36-44, February.

Chang R. and A. Velasco (1998) Financial Crises in Emerging Markets: A Canonical Model, NBER WP 6606.

Chinn M. (2000) Before the fall: Were East Asian currencies overvalued? Emerging Markets Review, 1(2), 101-126.

Chui M. (2002) Leading indicators of balance-of-payment crises: A partial review, WP Bank of England.

Chui M. and Gai P. (2005) Private Sector Involvement and International Fianancial Crises: An Analytical Perspective, Oxford University Press, Oxford.

Cooper R. (2007) Understanding Global Imbalances, Brooking Papers on Economic Activity, 2, 237-280.

Corden M. (2007) Those Current Account Imbalances: A Sceptical View, The World Economy, 30, 363-382.

Corsetti G., Pesenti P. and Roubini N. (1999) What caused the asian currency and financial crisis?, in: CEPR-World Bank Conference on Financial Crises: Contagion and Market Volatility, London.

De Finetti B. (1938) Resoconto critico del colloquio di Ginevra intorno alla teoria della probabilità, Giornale dell'Istituto italiano degli Attuari.

Deutsch J. and Silber J. (1997) Gini's transvariation and the measurement of the distance between distributions, Empirical Economics, 4, 547-554.

Dornbusch, R. and S. Fischer (2003), International Financial Crises, Working Paper, n.926, CESIFO.

Eichengreen B., Rose A. and Wyplosz C. (1995) Exchange market mayhem: The antecedents and aftermath of speculative attacks, Economic policy. 
Eichengreen, B. (2007), Global Imbalances and the Lessons of Bretton Woods, The Cairoli Lectures, MIT Press, Cambridge MA.

Eadie W., Drijard D., James F., Roos M. and Sandaoulet B. (1981) Statistical Methods in Experimental Physics, North Holland, Amsterdam.

Edwards S. and Santaella J. (1992) Devaluation controversies in the developing countries: Lessons from the Bretton Woods era, NBER Working Papers, 4047.

Edwards, S. (2002), "Does Current Account Matters?", in Edwards, S. and J. Frankel, Preventing Currency Crises in Emerging Markets, p. 1-18.

Edwards, S. (2004), Thirty Years of Current Account Imbalances, Current Account Reversals and Sudden Stops, NBER Working Paper, n. 10276.

Edwards, S. (2005), "The End of Large Current Account Deficits, 1970-2002: Are There Lessons for the United States?”, NBER Working Paper, n.11669.

Edwards, S. (2007), On current account surpluses and the correction of global imbalances, NBER Working Paper, n. 12904.

Eichengreen B. (2007), Global Imbalances and the Lessons of Bretton Woods, MIT Press.

Flood R. and Garber P. (1984) Collapsing exchange rates regimes: Some linear examples, Journal of International Economics, 17, 1-13.

Frankel J. and Rose A. (1996) Currency crashes in emerging markets: An empirical treatment, Journal of International Economics, 41, 351-366.

Frankel J. and Saravelos G. (2010) Are Leading Indicators Useful for Assessing Country Vulnerability? Evidence from the 2008-09 Global Financial Crisis, NBER WP no. 16047.

Gini C. (1916) Il concetto di transvariazione e le sue prime applicazioni, Giornale degli economisti.

Gini C. (1951) Della misura sintetica della transvariazione rispetto ad n caratteri, Atti della XI riunione scientifica della società italiana di statistica.

IMF (2001) International Financial Statistics Yearbook, volume LIV, Washington D.C.

Kaminsky G. (1999), Currency and Banking Crises - the Early Warning of Distress, IMF WP 99/178

Kaminsky G. (2006) Currency crisis: Are they all the same?, Journal of International Money and Finance, 25, 503-527. 
Kaminsky G. and C.M. Reinhart (1999), The Twin Crisis: the Causes of Banking and Balance of Payments Crises, American Economic Review, 89 (3), 479-500.

Kaminsky G., Lizondo S. and Reinhart C. (1997) Leading indicators of currency crises, Policy Research Working Paper, World Bank, 1852.

Krugman P. (1979) A model of balance-of-payment crises, Journal of Money, Credit and Banking, 11, 311-325.

Krugman P. (1998) Analytical Afterthoughts on the Asian Crisis, mimeo, Princeton University.

Krzanowski W. and Marriot F. (1995) Classification, Covariance Structures and Repeated Measurements, Arnold, London, volume 2.

Martinez Peria M.S. ( 2002), A regime-switching approach to the study of speculative attacks: A focus on EMS crises, Empirical Economics, Springer, vol. 27(2), pages 299334.

Manasse P., Roubini N. and Schimmelpfennig A. (2003), Predicting Sovereign Debt Crises, IMF Working Paper 03/221.

Matusita K. (1956) Decision rule, based on distance, for the classification problem, Annals of the institute of statistical mathematics, 8, 67-77.

McKinnon R. (2001) The international dollar standard and sustainability of the US current account deficit, Brookings Panel on Economic Activity: Symposium on the U.S. Current Account.

Moody's Global Credit Research, Sovereign Default and Recovery Rates, 1983-2007, March 2008.

Obstfeld M. and Rogoff K. (1995) Exchange rate dynamics redux, Journal of Political Economy, 103, 624-660.

Radelet S. and Sachs J. (1998a) The Onset of the East Asian Financial Crisis, mimeo, Harvard Institute for international development.

Radelet S. and Sachs J. (1998b) The east Asian financial crisis: Diagnosis remedies and prospects, Brookings Papers on Economic Activity, 1-90.

Reinhart, C. and K. Rogoff (2009), This Time is Different: Eight Centuries of Financial Folly, Princeton University Press.

Reinhart, C.M. and Reinhart, V. R.(2010), After the Fall, NBER WP no. 16334. 
Rose, A. and M. Spiegel (2009) The Causes and Consequences of the 2008 Crisis: Early Warning, NBER WP, no. 15357.

Salant S. and Henderson D. (1978) Market anticipation of government policy and the price of gold, Journal of Political Economy, 86, 627-648.

Skirmantas J. (2005) Statistical distribution of blood serotonin as a predictor of early autistic brain abnormalities, Theoretical biology and medicine modelling, 2, 27.

Williamson, J. (2005) Curbing the Boom-Bust Cycle: Stabilizing Capital Flows to Emerging Markets. Policy Analyses in International Economics. Institute for International Economics, Washington, DC.

Wolf, M. (2009), Fixing Global Finance, Yale University Press. 
Table 1: Quartile analysis ${ }^{19}$

\begin{tabular}{|c|c|c|c|c|c|c|c|c|c|c|c|}
\hline \multicolumn{6}{|c|}{ trade balance/GDP } & \multicolumn{6}{|c|}{ investment/GDP (variation) } \\
\hline & -4 & -2 & crisis & control(1) & control(2) & & -4 & -2 & crisis & control(1) & control(2) \\
\hline $1 \mathrm{Q}$ & -3.6 & -4 & -0.3 & -2.1 & -0.0 & 1Q & -5 & -5.3 & -9.9 & -1 & -5.2 \\
\hline $\mathrm{Me}$ & -0.5 & -0.3 & 2.8 & 2.3 & 0.0 & $\mathrm{Me}$ & -1 & -0.9 & -4.5 & 0.7 & -1.7 \\
\hline $3 \mathrm{Q}$ & 3.4 & 5.2 & 8.1 & 4.1 & 0.1 & $3 \mathrm{Q}$ & 3.4 & 2.6 & 1.3 & 2.8 & 1.3 \\
\hline \multicolumn{6}{|c|}{ savings/GDP (variation) } & \multicolumn{6}{|c|}{ GDP growth } \\
\hline & -4 & -2 & crisis & control(1) & control(2) & & -4 & -2 & crisis & control(1) & control(2) \\
\hline 1Q & -7.2 & -11 & -4.9 & -7.2 & -11.3 & $1 \mathrm{Q}$ & 2.8 & -1.6 & -18 & 1.7 & -0.2 \\
\hline $\mathrm{Me}$ & -0.4 & -0.9 & -2.6 & -0.5 & -2.8 & $\mathrm{Me}$ & 8.7 & 8.9 & -5.1 & 3.1 & 2.6 \\
\hline $3 \mathrm{Q}$ & 5.2 & 1.1 & 1.4 & 2.3 & 11.1 & $3 \mathrm{Q}$ & 13.1 & 15.8 & -2.1 & 4.1 & 3.6 \\
\hline \multicolumn{6}{|c|}{ reserves variation } & \multicolumn{6}{|c|}{ CAD/GDP } \\
\hline & -4 & -2 & crisis & control(1) & control(2) & & -4 & -2 & crisis & control(1) & control(2) \\
\hline 1Q & 8.4 & -11.3 & -37.3 & -30.7 & -0.3 & $1 \mathrm{Q}$ & -4.5 & -6.2 & -4.5 & -1.7 & -0.6 \\
\hline $\mathrm{Me}$ & 20.2 & 13 & -22.6 & -10.4 & 6.9 & $\mathrm{Me}$ & -3.2 & -3.2 & -3 & 1.2 & 1.6 \\
\hline $3 \mathrm{Q}$ & 34 & 31.3 & -10.3 & 12 & 30.0 & $3 \mathrm{Q}$ & -1.3 & -1.9 & -1.8 & 4 & 4.6 \\
\hline \multicolumn{6}{|c|}{ M2/reserves (variation) } & \multicolumn{6}{|c|}{ real deposit rate (variation) } \\
\hline & -4 & -2 & crisis & control(1) & control(2) & & -4 & -2 & crisis & control(1) & control(2) \\
\hline 1Q & -18.5 & -11.7 & 4 & -13.1 & -14.7 & 1Q & -59.2 & -81.9 & -59.3 & -47.1 & -231.0 \\
\hline $\mathrm{Me}$ & -1.2 & 1.3 & 24.4 & -9.4 & -9. & $\mathrm{Me}$ & -2.2 & 29.6 & -3.9 & -30 & -50.4 \\
\hline $3 \mathrm{Q}$ & 2 & 25.6 & 38.8 & -2 & -6.5 & $3 \mathrm{Q}$ & 2.7 & 83.6 & 94.4 & -15.3 & 4.1 \\
\hline \multicolumn{6}{|c|}{ domestic credit/GDP } & \multicolumn{6}{|c|}{ M2/GDP (variation) } \\
\hline & -4 & -2 & crisis & control(1) & control(2) & & -4 & -2 & crisis & control(1) & control(2) \\
\hline 1Q & -1.8 & -1.3 & -3.7 & -5.1 & -10.50 & $1 \mathrm{Q}$ & -11.1 & -2.9 & -3.5 & -3.2 & -4.8 \\
\hline $\mathrm{Me}$ & 4.3 & 4.2 & 6.6 & 3 & -6.5 & $\mathrm{Me}$ & 2.6 & 3.8 & 0 & 1.1 & 0. \\
\hline $3 \mathrm{Q}$ & 8.1 & 9 & 16.2 & 4.3 & 2.30 & $3 \mathrm{Q}$ & 12.6 & 6.8 & 7.6 & 6 & 8.6 \\
\hline \multicolumn{6}{|c|}{ nominal deposit rate (variation) } & \multicolumn{6}{|c|}{ inflation (variation) } \\
\hline & -4 & -2 & crisis & control(1) & $\operatorname{control}(2)$ & & -4 & -2 & crisis & control(1) & control(2) \\
\hline 1Q & -22.6 & -11 & 1.8 & -33.2 & -20.0 & $1 Q$ & -28.9 & -51.4 & -27.7 & -33.4 & -2.7 \\
\hline $\mathrm{Me}$ & -5.1 & 0.7 & 12.7 & -20 & 0.2 & $\mathrm{Me}$ & 0 & -15.5 & -2.2 & -0.5 & 67.1 \\
\hline $3 \mathrm{Q}$ & 0 & 13.7 & 44 & -12.3 & 19.3 & $3 \mathrm{Q}$ & 24.6 & 9.2 & 46.3 & 32 & 79.2 \\
\hline
\end{tabular}

19 control (1) comprises the group of developed countries in 1999, control (2) comprises the developing countries of the sample group 4 years after the crisis. 
Table 2: Transvariation probability index (developed countries as control group)

\begin{tabular}{lccccc}
\hline & $\mathbf{- 4}$ years & $\mathbf{- 3}$ years & $\mathbf{- 2}$ years & $\mathbf{- 1}$ years & crisis \\
\hline CAD/GDP & 0.54 & 0.46 & 0.49 & 0.40 & 0.41 \\
M2/GDP (variation) & 0.92 & 0.91 & 0.91 & 0.44 & 1.00 \\
M2/Reserves (variation) & 0.84 & 0.61 & 0.69 & 0.49 & 0.41 \\
Domestic credit /GDP (variation) & 0.83 & 0.92 & 0.82 & 0.53 & 0.74 \\
Inflation (variation) & 0.93 & 0.91 & 0.78 & 0.72 & 0.93 \\
Nominal Deposit Rate (variation) & 0.64 & 0.82 & 0.51 & 0.66 & 0.19 \\
Reserves (variation) & 0.57 & 0.71 & 0.69 & 0.72 & 0.70 \\
Trade Balance/GDP & 0.84 & 0.75 & 0.90 & 0.90 & 0.79 \\
Savings/GDP (variation) & 1.00 & 0.93 & 0.91 & 0.85 & 0.92 \\
Real interest rate (variation) & 0.62 & 0.94 & 0.58 & 0.77 & 0.73 \\
Investment/GDP (variation) & 0.80 & 0.90 & 0.85 & 0.91 & 0.57 \\
GDP per capita growth & 0.55 & 0.34 & 0.66 & 0.90 & 0.29 \\
\hline
\end{tabular}

Table 3: Transvariation probability index (developing countries as control group)

\begin{tabular}{lccccc}
\hline & $\mathbf{- 4}$ years & $\mathbf{- 3}$ years & $\mathbf{- 2}$ years & $\mathbf{- 1}$ year & crisis \\
\hline CAD/GDP & 0.37 & 0.35 & 0.34 & 0.32 & 0.24 \\
M2/GDP (variation) & 0.44 & 0.60 & 0.63 & 0.59 & 0.73 \\
M2/Reserves (variation) & 0.58 & 0.29 & 0.36 & 0.44 & 0.21 \\
Domestic credit /GDP (variation) & 0.59 & 0.38 & 0.51 & 0.51 & 0.48 \\
Inflation (variation) & 0.60 & 0.57 & 0.46 & 0.47 & 0.68 \\
Nominal Deposit Rate (variation) & 0.60 & 0.73 & 0.87 & 0.97 & 0.63 \\
Reserves (variation) & 0.65 & 0.86 & 0.92 & 0.97 & 0.10 \\
Trade Balance/GDP & 0.67 & 0.57 & 0.58 & 0.54 & 0.54 \\
Savings/GDP (variation) & 0.76 & 0.93 & 0.94 & 0.86 & 0.88 \\
Real interest rate (variation) & 0.81 & 0.59 & 0.25 & 0.44 & 0.56 \\
Investment/GDP (variation) & 0.87 & 0.90 & 0.94 & 0.95 & 0.76 \\
GDP per capita growth & 0.99 & 0.94 & 0.90 & 0.96 & 0.68 \\
\hline
\end{tabular}


Table 4: Speed of run of the current account deficit

\begin{tabular}{lcccccccccccc}
\hline & 90 & 91 & 92 & 93 & 94 & 95 & 96 & 97 & 98 & 99 & 00 & score \\
\hline Indonesia & - & - & - & - & - & - & - & - & + & + & + & 7 \\
Malaysia & - & - & - & - & - & - & - & - & + & + & + & 7 \\
Philippines & - & - & - & - & - & - & - & - & + & + & + & 7 \\
Korea & - & - & - & + & - & - & - & - & + & + & + & 3 \\
Thailand & - & - & - & - & - & - & - & - & + & + & + & 7 \\
Pakistan & - & - & - & - & - & - & - & - & - & - & - & 8 \\
Brazil & n.a. & n.a. & n.a. & n.a. & - & - & - & - & - & - & - & 5 \\
Mexico & - & - & - & - & - & - & - & - & - & - & - & 4 \\
Ecuador & - & - & - & - & - & - & + & - & - & + & n.a. & 1 \\
Venezuela & + & + & - & - & + & + & + & + & - & + & + & 0 \\
Russia & n.a. & n.a. & n.a. & n.a. & + & + & + & + & - & + & + & 0 \\
Ukraine & n.a. & n.a. & n.a. & n.a. & n.a. & - & - & - & - & + & n.a. & 3 \\
Ivory Coast & - & - & - & - & - & - & - & - & - & n.a. & - & 9 \\
Peru & + & - & - & - & - & - & - & - & - & - & - & 10 \\
Argentina & n.a. & - & - & - & - & - & - & - & - & - & - & 10 \\
Turkey & & n.a & n.a. & n.a. & n.a & - & - & - & + & - & - & 2 \\
Indonesia & - & - & - & - & - & - & - & - & + & + & + & 7 \\
\hline
\end{tabular}

Table 5: Transvariation probability index

\begin{tabular}{|l|c|c|}
\hline & $\begin{array}{c}\text { developed countries } \\
1971-1973\end{array}$ & $\begin{array}{c}\text { developed countries } \\
2004-2006\end{array}$ \\
\hline CAD/GDP & 0,247 & 0,440 \\
\hline M2 growth & 0,508 & 0,500 \\
\hline GDP per capita growth & 0,249 & 0,650 \\
\hline Government debt (\%GDP) & n.a & 0,800 \\
\hline Investment/GDP (variation) & 0,946 & 0,880 \\
\hline Toatal Reserves (variation) & 0,501 & 0,890 \\
\hline Domestic credit /GDP (variation) & 0,660 & 0,940 \\
\hline Short Term Debt (\% of GDP) & n.a & 0,950 \\
\hline External Debt (\% of GDP) & n.a & 0,970 \\
\hline Inflation (variation) & 0,920 & 1,000 \\
\hline
\end{tabular}

